Higher School of Agribusiness in Lomza,

Poland

dariusz.brakoniecki@gmail.com

ORCID iD: https://orcid.org/0000-0001-7967-9172

MARCIN KIEŁCZEWSKI

Advocate Office Marcin Kiełczewski, Warszawa, Poland

adwokatmarcinkielczewski@gmail.com

\title{
THE TERM OF OFFICE OF ELECTING THE SUPERVISORY BOARD AS THE PERIOD CORRESPONDING TO INTERNSHIP IN A MANAGEMENT POSITION
}

\begin{abstract}
Managing human capital, directing enterprises or institutions, as well as broadly understood management has always been a task requiring special skills. It is mainly about the knowledge of issues in the area of operation of a given entity, but also of widely developed "soft skills". Essential for the development of these competencies is - experience in executive positions, which the legislator very often requires from people applying for management positions in state units.

The essential element of the work is to present the tasks of the members of the supervisory board, whose nature is the same or similar to the tasks of management staff. That is to prove the thesis set out in the title of the article that the function of a supervisory board member is a managerial function. The study contains an analysis of the principal legal acts from the systemic and institutional perspective in Poland. This article is a theoretical work, based mainly on cognitive research, using the historical-legal, dogmatic-legal and comparative methods.
\end{abstract}

KEYWORDS: supervisory board, seniority, management position, management, commercial law 


\section{INTRODUCTION}

The main point of considerations in the title scope is to define the concept of "management position". Although the institution of the supervisory board is the domain of commercial law, the starting point for analysis in this area is labor law and jurisprudence. Regarding to the possibility of crediting the period of performing the function of a supervisory board member towards an internship in an executive position, one should first consider the provisions of the Act of September 15, 2000, Code of Commercial Companies (Journal of Laws 2020, item 1526), the Act of March 3, 2000, on the remuneration of persons managing certain legal entities (Journal of Laws 2019, item 2136) and archival files, Resolution No. 394 of the Council of Ministers of September 17, 1959, on the definition of management and other independent work positions (MP No. 84/59 item 444) and the regulation of the Council of Ministers of November 20,1974, on the definition of executive positions in which employees are employed based on appointment (Journal of Laws 1974 No. 45 item 268).

\section{MANAgEMENT POSITION IN LABOR LAW}

The analysis of the provisions of the labor law indicates a wide variety of terminology - sometimes completely unjustified - used to denote the subjective scope of "managerial staff". In the Labor Code, the legislator uses such terms as: "managing employees, on behalf of the employer, the workplace", "person or body managing the organizational unit for the employer", "managing persons, on behalf of the employer, the workplace" or "managers of separate units organizational ". In addition to the terms indicated here, the provisions of the Labor Code (Journal of Laws 2020, item 1320) also include the category of "people managing employees" who are obliged to fulfill the obligations in the field of occupational health and safety specified in art. 212 of the Labor Code, for the breach of which is subject to criminal liability, pursuant to Art. $283 \$ 1$ of the Labor Code. In turn, in the Act of May 23, 1991, on trade unions (Journal of Laws of 2019, item 263), the term "managerial staff" is used. Pursuant to Art. $32 \mathrm{sec} .5$ of the cited act, the persons who constitute the managerial staff in the workplace are single- 
person managers of the workplace and their deputies or members of the collective body managing the workplace, as well as other persons appointed to perform activities in the field of labor law for the employer (Duraj, 2013) .

A drawback of the applicable regulations is the lack of a universal definition of the term "managerial employee" uniformly defining, at least for the purposes of the code regulation, the subjective scope of this term. In the labor law, the legislator does not specify the catalog of positions that should be generally considered as managerial in every workplace. Even if the provisions of the labor law specify the concept of a managing employee, most often this definition has a different subjective scope and is created for the needs of strictly defined labor law institutions (Duraj, 2013). According to the doctrine (see: Bury, 2011, p. 121; Pisarczyk, 2011, p. 755; Patulski, 2001, pp. 25-26; Jaśkowski, Maniewska, 2001, p. 334; Duraj, 2005, p. 19) two criteria can be distinguished, the fulfillment of which determines the qualification of a given person to the category of "managers of separate organizational units". The first is the appropriate separation of an organizational unit that is the subject of management; the second- assigning basic importance to managerial tasks in the manager's employment relationship in the scope of his official duties (Duraj, 2013). Attempts to define the first of the concepts were made by the Supreme Court in the judgment of 12 July 2005 (II PK 383/04, OSNP No. 7-8 / 2006, item 112), in which it states that the term "separate organizational unit" does not always have to be directly related to a permanent organizational chart. According to the Supreme Court, it is also possible to include ad hoc organizational units with this conceptual category, to achieve a specific goal, to perform certain specific (one-time, time-limited) tasks.

The second criterion for qualifying a particular person to the category of "managers of separate organizational units" is their scope of duties, the content of which should be played by managerial tasks in the management of a given organizational unit of the workplace. In the literature on the subject (see: Nowak, 2008, p. 218) and judicial decisions, it is commonly assumed that the head of a separate organizational unit can only be an employee whose duties relate exclusively or predominantly concern organizing and managing employees' work. In the judgment of December 15, 2006, the Administrative 
Court in Katowice (III APa 176/05, OSA in Katowice No. 3/2007, item 6) stated that the essence of "the work performed by the management staff is that the work performed by them is managing a team of people organized in a separate organizational unit, the essence of this work is precisely the performance of managerial activities "(Duraj, 2013).

Further case law clarifies the concept of a management position. In the judgment of January 13, 2005, the Supreme Court (II PK 114/04, OSNP 2005, No. 16, item 245) stated that an employee who performs work on an equal basis with other team members will not be treated as an employee in a managerial position. Then, in the judgment of 8 June 2004, (III PK 22/04, OSNP 2005, No. 5, item 65), the Supreme Court (when assessing the scope of duties of such an employee) stated that not only the provisions of the employment contract should be taken into account, but also the actual manner of performing the employment relationship, in particular, whether the employee: organized and supervised the work of other team members, determined their working hours, granted them dismissals, and finally whether the employee made decisions on hiring new employees.

\section{MANAGEMENT POSITION IN COMMERCIAL LAW}

The Act of 15 September, 2000, Commercial Companies Code (CCC) (Journal of Laws 2019, item 505) regulates issues related to the supervisory board in the company. The company's supervisory board is, in principle, a body that performs strictly supervisory functions, which concept is defined as having a very broad meaning. "There are important differences between supervision and control. First of all, supervision differs from the control in the scope of actions that can be taken, because control is the right to look into the activities of a given entity as well as request information and explanations, but supervision also includes the right to take actions involving of the controlled entity. The concept of supervision is therefore broader than control. Moreover, the supervision is permanent (cf. remarks contained in $\$ 1$ ). The concept of supervision related to the supervisory board in a limited liability company distinctly covers the control competences, while the provisions of the Code of Commercial Companies do not expressly indicate the right of the supervisory 
board to issue orders to the supervised, in particular the management board, in connection with the performed supervision. However, it should be argued that such actions are permissible due to the fact that they express the essence of supervision that distinguishes it from control. There are four main groups that can be distinguished among the powers of the supervisory board. The first is supervisory and control competencies, which constitute the core group of rights and obligations for which this body is established. However, the second group includes additional rights granted in the articles of association pursuant to Art. 220 of the Commercial Companies Code and other dispositive provisions of the Commercial Companies Code. The third groups are the rights and obligations of an organizational nature related to ensuring the proper functioning of the company. On the other hand, the fourth group includes the powers of the supervisory board to represent the company. The supervisory board does not have the authority to run the company's affairs, but by exercising the indicated competencies, it may influence them. (Kidyba, 2014, Part 4, Chapter 12 \$6).

The supervisory board may influence on the current operation of the company by means of instructions, advice, guidelines. In addition to the prohibition on issuing orders to the management board in the conduct of the company's affairs pursuant to Art. $219 \$ 2$ of the Commercial Companies Code other ways of influencing should be kept in mind. The Supervisory Board may influence on the current operations of the company by means of orders that are de facto non-binding, but constitute some advice, indication, guidelines, suggestions, recommendations, and may also make decisions binding the company (in the form of resolutions or consents to activities), and then has the ability to authoritatively interfere in its activities. Ignoring the position of the supervisory board may constitute grounds for recognizing the lack of due diligence on the part of management board members. The ban on issuing binding instructions by the council does not preclude the boards (concerning to management boards) from formulating postulates regarding the running of the company's affairs. The management boards are not obliged to take them into account. However, it is essential thatignoring them could result in organizational liability of management board members, i.e. their suspension or dismissal. The ban on issuing binding 
orders by councils to management boards negatively assesses Postuła. In his opinion- this ban is an expression of "excessive faith in the omnipotence of managers", reduces the mutual trust of management boards and supervisory boards and hinders the cooperation of these bodies. The author also claims that this solution is in contradiction with contemporary trends in corporate governance, which in response to the phenomena of widespread abuse of managers and corporate scandals, clearly support increasing the role of supervisory bodies. (Postuła, 2013).

An important element that is often overlooked in the context of the powers of the supervisory board is the identification of the addressee to whom Art. $219 \$ 2$ of the Commercial Companies Code imposes a ban on directing commands. The literal content of the provision indicates that it forbidden to send binding instructions concerning the management of the company's affairs to the management board. Therefore, there is nothing to prevent the supervisory board from giving binding instructions to employees of the company other than the management board. "The prohibition of issuing binding instructions does not apply to organizational activities in which the supervisory board is also guaranteed certain powers instead of the management board (e.g. convening the shareholders' meeting) or in addition to the management board. Moreover, due to the fact that the management board is obliged to perform these activities anyway, additional interference of the council would only confirm an order to perform them resulting from the act (e.g. an order to keep a shared book when the management board does not keep it). Finally, the prohibition applies to issuing binding orders to the management board but does not extend to other persons, in particular, the company's employees, persons reporting directly to members of the management board, branch managers. (Kidyba, 2014, Part 4, Chapter $12 \$ 6$ ).

In the context of this opinion, a particularly important provision is Art. 220 of CCC, which allows to extending the powers of the supervisory board. In particular, this provision emphasizes each time the management board obtains the consent of the supervisory board before performing certain actions. On the one hand, the supervisory board cannot issue binding orders as to the conduct of the company's affairs, which should be regarded as a rule. On the other hand, the articles of association may extend the 
powers of the supervisory board, which should be considered an exception to the above-mentioned rule. However, it should be recognized that the management board of a limited liability company will always be bound by resolutions of the supervisory board when the articles of association provide for it. There is nothing to prevent the articles of association from including a provision stating that the management board is subject to and is bound by resolutions of the supervisory board. It results from the content of Art. 207 of the Commercial Companies Code, which binds the management board with all the limitations contained in the articles of association. The articles of association may also provide that the management board of the limited liability company is bound by the limitations contained in the resolutions of the audit committee. In conclusion, it should be stated that the management board of the limited liability company is not bound by the resolutions of the supervisory board and the audit committee unless it is clearly stated in the articles of association or in the resolution of the partners meeting. (Szczęsny, 2004).

The first of the group of exemplary powers that the legislator emphasizes is the requirement obtaining the consent of the supervisory board to perform specific activities. Examples of activities that may be the subject of the abovementioned regulation:

1. Selling and acquiring real estate or perpetual rights or property shares with a value above a certain amount,

2. Acquisition or disposal other than non-current asset real estate with a value above a certain amount,

3. Incurring liabilities by the company, issuing promissory notes, granting guarantees and property sureties by the company above a certain amount,

4. Establishing a branch of the company.

Another right in the context of Art. 220 of CCC is a possibility to suspend individual or all members of the management board for important reasons. "This right is vested in the supervisory board in a limited liability company only if the partnership agreement provides it (as opposed to a joint-stock company, see Art. $383 \$ 1$ of the Code of Commercial Companies). The 
essence of the suspension is expressed in the fact that the mandate of a management board member does not expire. However, a management board member may not exercise the rights and obligations resulting from the mandate. The suspension applies to all activities that a management board member is authorized or obliged to perform, i.e. it covers both activities related to running the affairs and representing the company, as well as other activities regulated in the provisions of the Commercial Companies Code and in special regulations. The suspension of duties may concern individual or even all members of the management board. Thanks to this power, the supervisory board gains the possibility to significantly interfere in the company's affairs, because its performance may affect not only the internal functioning of the company, but also the company's performance of legal transactions. In particular, this may prevent the company from performing such activities when the number of the remaining members of the management board does not allow meeting the requirements of the articles of association or the act in terms of the manner of representation. (Kidyba, 2014, Part 4, Chapter $12 \$ 6$ ).

An example of additional powers of the supervisory board may include many issues covered by the articles of association based on other applicable provisions of the Code of Commercial Companies and Partnerships such as:

1. Adopting the regulations of the management board or the right to set remuneration for members of the management board,

2. The right to appoint or dismiss members of the management board,

3. The right to decide whether to decide on profit distribution or loss coverage

Another group of rights are pursuant to Art. 220 of CCC are the organizational powers of the supervisory board, which ensure the proper functioning of the company. These include the right to request the convening of an extraordinary partners' meeting if the council deems it to be an indication, the right to convene an ordinary associates' meeting if the management board fails to convene it within six months after the end of the financial year, or the right to bring an action to repeal the partners' resolution and to annul the resolution. 
The last group of powers of the supervisory board covers activities related to the representation of the company. However, this results from the provision of $21 \$ 1$ of the Commercial Companies Code, which indicates the supervisory board as the body authorized to represent the company in contracts and disputes between the company and a member of the management board. The indicated right applies to all contracts between these entities, e.g. employment contracts, mandate contracts, managerial contracts, but also lease or sale contracts.

It is worth noting that the provision of Art. 220 of the CCC contains only examples of competences, literally using the phrase "in particular". This structure enables the introduction of additional, non-code competences of the supervisory board.

The last element that indicates the possibility of direct influence on the company is delegating a member of the company's supervisory board to perform the duties of a management board member. This was not specified directly, but in analogy to the provisions of Art. $381 \S 1$ of the Code of Commercial Companies and Partnerships is possible pursuant to Art. 220 of CCC. By granting such a right to the supervisory board, the owner or partner of a limited liability company may ensure smooth functioning in its structure in the event of sudden appeals or unforeseen resignations. Delegating the management of the company is possible only if there are relevant provisions in the articles of association. Due to the delegation, the authority in the supervisory board of the delegated person is suspended.

Referring to other legal acts, in the current system; there is no definition of a managerial position that would correspond to the current economic situation. Both the Labor Code and the Code of Commercial Companies do not define this concept. Only two archival legal acts, i.e. Resolution No. 394 of the Council of Ministers of September 17, 1959, on the determination of managerial and other independent work positions and the Regulation of the Council of Ministers of November 20, 1974, on the definition of managerial positions for which employees are employed on the basis of appointment - define the list of managerial positions. Due to the dates of these legal acts, which at that time did not know the 
institution of supervisory boards, they certainly cannot be a determinant of all positions that can be indicated as managerial or identical.

The Act of March 3, 2000, on Remuneration of Persons Managing Certain Legal Entities (Journal of Laws of 2019, item 2136, i.e.) is the only legal act that can be used when determining managerial or identical positions, due to its topicality in the context of currently known functions and corporate bodies. Art. 2 sec. 7 of this Act covers members of the supervisory board of commercial companies. The purposive interpretation of the cited provision of the Act, of persons managing certain legal entities in the context of the abovementioned competences of the supervisory board - indicates the same scope of terms as a managerial position and a supervisory board member under the Act.

\section{Conclusions}

After analyzing the presented legal status and the principles of applying legal norms, as well as the position of the doctrine in this area, it should be undoubtedly stated that the competences of a supervisory board member indicate a much wider range of possibilities of influencing on the actual functioning of the company than people in management positions that fall under the company's management.

There is no legal definition of an executive position in the applicable law and case law. In the non-binding Resolution No. 394 of the Council of Ministers of September 17, 1959, on the determination of managerial and other independent job positions, and the non-binding Regulation of the Council of Ministers of November 20, 1974, on the definition of management positions for which employees are employed based on an appointment, there is only an open catalog of positions considered as managerial. The decisions made at the time do not correspond to the organizational structure of the currently functioning legal entities. The use of the Act of March 3, 2000, on Remuneration of Persons Managing Certain Legal Entities in a clear, logical and functional manner allows for the definition of executive positions and positions recognized as being identical to executive positions. This Act, in Art. 2 point 7 indicates that it applies to members of supervisory bodies of organizational units. 
Bearing in mind the scope of competences of a supervisory board member of a limited liability company, i.e. responsibility and special competences granted under the freedom to shape contracts (pursuant to the provisions of the Act of September 15, 2000, Code of Commercial Companies in connection with the Act of March 3, 2000, on remunerating persons managing certain legal entities) enables it to recognize the period of performing the function of a member of the supervisory board as being identical with the seniority in a management position. The possibility of delegating a supervisory board member to perform the function of a management board member fully legitimizes the thesis of equating the period of performing the function of a supervisory board member with the period of work in a management position.

\section{References}

Bury B. (2007). Praca $w$ godzinach nadliczbowych, Warsaw: C.H. Beck. ISBN 9788374839853.

Duraj T. (2005). Pojęcie osoby zarządzającej w imieniu pracodawcy zakładem pracy, Praca i Zabezpieczenie Społeczne Nr 6/2005. ISSN 0032-6186.

Duraj T. (2013). Pojęcie „kierownika wyodrębnionej komórki organizacyjnej” w świetle kodeksowych przepisów o rekompensacie za prace w godzinach nadliczbowych. Monitor Prawa Pracy 7/2013. czasopisma.beck.pl

Jaśkowski K., Maniewska E. (2001). Kodeks pracy. Komentarz. Cracow: C. H. Beck.

Kidyba A. (2014). Spółka z ograniczonq odpowiedzialnością. Komentarz. LEX. ISBN 9788325563011.

Nowak A. (2008). Glosa do wyroku SN z 12.7.2005 r., II PK 383/04, OSP no 3/2008, item. 33 .

Patulski A. (2001). Zatrudnianie i wynagradzanie kadry menedżerskiej średniego i wyższego szczebla. Gdańsk: Ośrodek Doradztwa i Doskonalenia Kadr. ISBN 8371874707.

Pisarczyk Ł. (2011). Dział VI-VII. in: L. Florek (ed.) Kodeks pracy. Komentarz. Warsaw: C.H. Beck

Postuła I. (2013). Nadzór Korporacyjny w spółkach Skarbu Państwa. LEX. ISBN 9788326442087. 
Szczęsny R. (2004). Zarząd w spółkach kapitałowych. LEX. ISBN 837333422X.

Act of September 15, 2000, Code of Commercial Companies. Journal of Laws 2020, item 1526.

Act of June 26, 1974 - Labor Code. Journal of Laws 2020, item 1320.

Act of March 3, 2000 on Remuneration of Persons Managing Certain Legal Entities. Journal of Laws 2019, item 2136.

Act of May 23, 1991 on trade unions. Journal of Laws 2019, item 263.

Judgment of the Supreme Court of 12 July 2005, II PK 383/04, OSNP No. 7-8/2006, item 112.

Judgment of the Supreme Court of 13 January 2005, II PK 114/04, OSNP 2005, no. 16, item 245.

Judgment of the Supreme Court of 8 June 2004, III PK 22/04, OSNP 2005, no. 5, item 65 .

Judgment of the Administrative Court in Katowice of 15 December 2006, III APa 176/05, OSA in Katowice No. 3/2007, item 6

Resolution No. 394 of the Council of Ministers of September 17, 1959 on defining managerial and other independent positions. MP No. 84/59 item 444, archival act.

Regulation of the Council of Ministers of November 20, 1974 on the determination of managerial positions for employment of employees by appointment. Journal of Laws 1974 No. 45, item 268, archival act. 